\title{
Katja Vuokko
}

\section{Klassikosta lukuromaaniksi: käännösstrategioiden vertailu Dickensin David Copperfield -suomennoksissa}

Käännökset ovat osa sitä kohdekulttuuria, johon ja jota varten ne tuotetaan. ${ }^{1}$ Tavalliselle lukijalle käännös edustaa itse teosta ja alkuperäisen kirjailijan ääntä, eikä käännöksen ja alkutekstin suhdetta välttämättä mietitä, ellei käännöksessä koeta olevan selkeitä puutteita kirjallisena tuotteena. Kääntäjä taas toimii välittäjänä alkutekstin ja kohdekielen sekä -kulttuurin välillä ja joutuu tasapainoilemaan näiden kahden välillä: toisaalta käännöksen tulee olla mahdollisimman uskollinen alkutekstille, toisaalta taas kääntäjän on otettava huomioon kohdeyleisönsä odotukset ja tietämys sekä kohdekulttuurissa vallitsevat käsitykset ja normit siitä, millainen on hyvä käännös. Tämä tasapainoilu aktualisoituu varsinkin silloin, kun nämä kaksi vaatimusta ovat ristiriidassa keskenään. Paikallisella tasolla yksi tavallisimmista käännösongelmista ovat kulttuurisidonnaiset elementit, kuten käsitteet, idiomit tai alluusiot, jotka ovat vieraita kohdekielessä ja -kulttuurissa. Tällaisten ongelmien ratkaisemiseen kääntäjät voivat käyttää erilaisia vaihtoehtoisia strategioita. Käännösstrategiat valitaan tarkoituksenmukaisesti ratkaisuksi kulloiseenkin käännösongelmaan, mutta valintojen taustalla vaikuttavat aina myös käsitykset käännettävästä teoksesta, kohdeyleisöstä ja siitä, miten ja missä määrin alkutekstissä esiintyvät vieraat kulttuuriset elementit tulisi välittää lukijoille.

Tässä artikkelissa tarkastelen sitä, miten Charles Dickensin romaanista David Copperfield (1849-1850) julkaistuissa suomennoksissa on ratkaistu teoksen kulttuurisidonnaisiin elementteihin liittyviä käännösongelmia, ja millaisia käännösstrategioita suomentajat ovat eri aikoina käyttäneet. David Copperfield on yksi ensimmäisistä suomen kielelle käännetyistä englantilaisen kirjallisuuden klassikoksi luokitelluista romaaneista, ja se on suomennettu kolme kertaa, vuosina 1879-1880, 1924 ja 1971. Suomennosten ilmestymisen välillä kuluneiden lähes sadan vuoden aikana on tapahtunut suuria muutoksia niin suomalaisessa käännös- ja kustannustoiminnassa, englannin kielen ja kulttuurin asemassa Suomessa kuin myös Dickensin arvostuksessa. Tarkastelen sitä, miten nämä muutokset näkyvät romaanin eri suomentajien käyttämissä käännösstrategioissa. Selvitän, onko englannin kielen ja englantilaisen kulttuurin muuttuminen suomalaisille tutummaksi 1900-luvun aikana vaikuttanut siihen, miten suomentajat ovat eri aikoina ratkaisseet tekstissä esiintyviin kulttuurisidonnaisuuksiin liittyviä käännösongelmia; toisaalta pohdin myös, mitä käytetyt käännösstrategiat voivat kertoa siitä, miten suomentajat kulloinkin hahmottivat kohdeyleisönsä, käännöksensä tehtävän sekä oman roolinsa ja tehtävänsä välittäjänä, ja mikä vaikutus teosten kustantajalla ja julkaisukontekstilla on saattanut olla suomennoksessa tehtyihin ratkaisuihin. 


\section{Dickensin vaiheista Suomessa}

Angloamerikkalainen kirjallisuus nousi keskeiseen asemaan kirjallisuussuomennosten lähteenä vasta 1900-luvulla. 1800-luvulla Suomen suhteet Britanniaan olivat ensisijaisesti taloudellisia, kun taas kulttuuriset siteet vahvistuivat suhteellisen myöhään. Ensimmäisiä suomalaisen porvarillisen lukijakunnan parissa laajempaa suosiota saaneita englantilaisia kirjailijoita olivat Dickens ja Walter Scott, joita myös suomennettiin 1870-luvulta lähtien (Eneberg 1960, 332). Englannista suomennetun kirjallisuuden osuus lisääntyi hitaasti 1890-luvulla ja 1900-luvun alussa, ja 1910-luvulla englanninkielisestä kirjallisuudesta tuli suurin suomennoskirjallisuuden ryhmä (Kovala 1992, 35).

Voidaan todeta, että Dickens kuului 1800-luvun Suomen kirjallisuuskaanoniin jo ennen kuin yhtäkään hänen romaaniaan oli suomennettu. Hänen teoksensa, kuten suurin osa tuon ajan kirjallisuudesta, olivat jo saavuttaneet Suomen etupäässä ruotsinkielisen lukijakunnan ruotsalaisten ja saksalaisten käännösten muodossa vuosisadan puolivälissä. Dickens oli suosittu ja arvostettu kirjailija 1800-luvun Suomessa myös kirjallisen eliitin keskuudessa. Osasyynä on varmasti ollut keskeisten vaikuttajien osoittama arvostus: esimerkiksi J. V. Snellman julkaisi Litteraturblad-lehdessään positiivisia arvioita Dickensistä ja suositteli hänen teoksiaan käännettäviksi (Riikonen 2013, 388-389). Ensimmäinen Dickens-suomennos, novellikokoelma Mugbyn rautatiehaara, julkaistiin vuonna 1869, mutta David Copperfield oli ensimmäinen Dickensiltä suomennettu pitkä romaani. 1800-luvun aikana ilmestyi yhteensä kymmenen Dickens-suomennosta, lähinnä lyhyempiä kertomuksia, ja vuonna 1883 kirjallisuuslehti Valvojassa $(13-14,413)$ todettiinkin, että Dickens oli kenties rakastetuin ja suosituin kirjailija Suomessa.

Englannissa ja muuallakin Euroopassa Dickensin arvostus laski 1800-luvun jälkipuoliskolla uusien kirjallisten suuntausten myötä, ja kriitikot ja kirjallinen eliitti suhtautuivat hänen tuotantoonsa pääasiassa ylenkatseellisesti aina 1920-luvulle asti (ks. esim. Hollington 2013, 2-5). Suhtautuminen Dickensiin muuttui vähitellen myös Suomessa: 1900-luvun alkupuolella Dickensiä pidettiin täkäläisissäkin kirjallisuuspiireissä viihdyttävänä mutta hieman lapsellisena luettavana (Rantavaara 1965, 272; Kovala 1992, 54-56). Toisaalta Dickensin teosten vilkkain suomennosvaihe oli juuri 1920- ja 30-luvuilla, jolloin häneltä käännettiin suomeksi yhteensä 14 teosta. Asennemuutoksen huomaa silti suomennosten esipuheissa, joissa yhtäältä kehutaan Dickensin humoristista kerrontatapaa, toisaalta anteeksipyytävästi todetaan hänen teoksiaan vaivaavat viat, kuten monisanaisuus, sentimentaalisuus ja liioittelu.

Sodan jälkeen Dickensin teoksia on julkaistu Suomessa harvakseltaan. Uusintapainoksia vanhoista suomennoksista on otettu tasaisesti, mutta ensikäännöksiä on ilmestynyt 30-luvun jälkeen vain kolme: Edwin Droodin arvoitus (suom. Risto Lehmusoksa, 1973) ja Kersti Juvan suomennokset romaaneista Nicholas Nicklebyn elämä ja seikkailut (1992) ja Kolea talo (2006). Myös viimeisimmät uudelleensuomennokset Dickensin 
pitkistä romaaneista ovat 1970-luvulta. Poikkeuksen muodostaa kestosuosikiksi noussut Dickensin joulutarina A Christmas Carol, joka on Churbergin tekemän vuonna 1878 ilmestyneen ensimmäisen suomennoksen jälkeen uudelleensuomennettu eri nimillä ainakin seitsemän kertaa. Tähän ei varmastikaan ole syynä suomennosten poikkeuksellisen nopea vanheneminen, vaan todennäköisemmin kaupalliset syyt ja kustantajien kilpailu joulukirjamarkkinoista.

Dickensin pitkistä romaaneista viisi on edelleen suomentamatta; tästä huolimatta hänen teoksistaan on julkaistu suomennoksia ja niiden uusintapainoksia enemmän kuin kenenkään muun brittiläisen 1800-luvun kirjailijan tuotannosta (Riikonen 2013, 397). Dickensiin erikoistuneita akateemisia tutkijoita Suomessa on edustanut lähinnä Irma Rantavaara, mutta Dickensiin ja hänen tuotantoonsa liittyviä pro gradu -töitä on tehty tasaisesti 50-luvulta lähtien, yhteensä yli 70 tutkielmaa (ks. Riikonen 2013, 394-397). Tälläkin perusteella Dickensin voi siis katsoa säilyttäneen asemansa englantilaisen romaanikirjallisuuden klassikkona Suomessa.

\section{David Copperfieldin suomentajat ja julkaisukontekstit}

Uudelleenkäännöksiä perustellaan usein käännösten vanhentumisella, mutta taustalla vaikuttavat monet muutkin tekijät, kuten kustantamojen välinen kilpailu. Uusin käännös ei välttämättä ole myöskään se, joka jää uusien painosten myötä elämään. Lisäksi käännösten korjaaminen on merkittävä uudelleenkääntämisen kanssa rinnakkainen ja osin kilpaileva ilmiö. (Paloposki \& Koskinen 2010, 29-49.) Nämä tekijät käyvät ilmi myös omassa tarkastelussani.

David Copperfieldin ensimmäinen suomennos ilmestyi vuosina 1879-1880, aikana, joka lasketaan vielä suomenkielisen kaunokirjallisuuden käännösvaiheeksi ennen omakielisen kirjallisuuden esiinmarssia (ks. Kovala 1992, 29). Suomen kirjakielen intensiivisin kehitysvaihe alkoi tässä vaiheessa olla ohi ja kaupallinen suomenkielinen kustannustoiminta oli aluillaan, vaikka suomenkielisen kaunokirjallisuuden julkaiseminen ei välttämättä ollutkaan vielä taloudellisesti kannattavaa. Suomennos- ja kustannustoiminnan taustalla vaikuttivatkin usein vielä ideologiset motiivit: fennomania ja pyrkimys kehittää suomenkielistä kulttuuria ja kirjallisuutta. (Ks. esim. Häggman 2008, 189-191.) Nämä tekijät vaikuttivat myös ensimmäisen David Copperfield-suomennoksen syntyyn.

Teoksen suomentanut Waldemar Churberg (1848-1924) oli 1870-1880-luvuilla merkittävä kaunokirjallisuuden suomentaja ja kustantaja. Hän oli lähtöisin ruotsinkielisestä perheestä, mutta voimakkaan fennomaanisen herätyksen myötä opiskeli suomen kielen ja ryhtyi toimimaan suomalaisuusaatteen hyväksi. Vuosina 1874-1884 Churberg toimitti kahta romaanisarjaa, joissa julkaistuista yhteensä kuudestatoista teoksesta seitsemän hän suomensi itse englanninkielisistä alkuteoksista. Churbergin voidaan sanoa olleen edellä aikaansa suosiessaan englanninkielistä kaunokirjallisuutta aikana, jolloin Pohjoismaat ja Saksa olivat vielä ensisijaisia kulttuuristen ja kirjallisten vaikutteiden lähteitä Suomessa. $^{2}$ 
"W. Churberg'in Romani-kirjasto" -sarjassaan Churberg ilmoitti kustantavansa "ainoastaan klassillisia teoksia, niinmuodoin semmoisia, joitten suuresta ja pysyväisestä arvosta mailman kirjallisuudessa kaikki pitävät yhtä mieltä ja joita sen vuoksi kaikki sivistyneet kansat ovat kiiruhtaneet käännösten kautta omaan kirjallisuuteensa yhdistämään” (ilmoitus David Copperfieldin takakannen sisäsivulla, 1879). Tässä sarjassa vuosina 1879-1880 ilmestynyt David Copperfield oli Churbergin laajamittaisin suomennostyö ja omana aikanaan kulttuuriteko: yhteensä 1023-sivuisena se oli pisin siihen mennessä suomen kielellä julkaistu kaunokirjallinen teos. Lisäksi David Copperfield oli ollut mukana Suomalaisen Kirjallisuuden Seuran (SKS) vuonna 1872 julkaisemalla listalla käännettäväksi suositeltavista klassikkoteoksista (Uusi Suometar 13.3.1872). ${ }^{3}$ Nämä seikat huomioitiin myös aikalaisarvosteluissa (Uusi Suometar 15.12.1879, Morgonbladet 19.12.1879, Kirjallinen Kunkauslehti 11/1880), ja teoksen valintaa pidettiin niissä erinomaisena. Myös suomennosta arvioitiin pääosin kiittävästi, vaikka sitä myös moitittiin liiankin sananmukaisesta alkutekstin noudattamisesta (Kirjallinen Kunkauslehti 11/1880).

Vuosisadan vaihteen molemmin puolin tapahtuneen kielellisen ja kirjallisen kehityksen myötä Churbergin suomennos koettiin ilmeisesti vanhahtavaksi jo 1900-luvun alussa. ${ }^{4}$ Vuonna 1924, 44 vuotta Churbergin suomennoksen jälkeen, Karisto julkaisikin teoksesta uudelleensuomennoksen J. A. Hollon kääntämänä. Hollo (1885-1967) oli merkittävä ja tuottelias suomentaja, joka käänsi uransa aikana yli 200 kirjaa. Hollon suomennoksia on pääosin pidetty erittäin laadukkaina ja monet niistä vaikuttavat kestäneen aikaa huomattavasti paremmin kuin muut aikalaissuomennokset; joistain on otettu uusintapainoksia vielä 2000-luvullakin. (Kovala 2007, 589-590.)

Hollon suomennos ilmestyi "Kariston klassillinen kirjasto" -sarjassa, jossa julkaistiin myöhemmin myös kolmen muun Dickensin romaanin suomennokset. Sarja oli kirjallisesti kunnianhimoinen ja siinä julkaistiin nimekkäiden romaanien lisäksi muun muassa antiikin ja filosofian klassikkoteoksia. Vaikka Dickensin arvostus kirjallisuuspiireissä oli tässä vaiheessa jo heikentynyt, kustantaja näyttää luokitelleen hänen teoksensa edelleen klassiseksi arvokirjallisuudeksi. Suomennokseen kirjoittamassaan esipuheessa Hollo (1924, 10) kuvaa Dickensiä erityisesti oman aikansa ja "vanhan Englannin idyllin" edustajana - nykylukijalle osin vanhahtavana, mutta edelleen nautittavana kirjailijana.

Siinä missä David Copperfieldin ensimmäinen suomennos toimi esimerkkinä kaupallisen kustannustoiminnan ideologisesti motivoituneesta alkuvaiheesta 1800-luvun jälkipuoliskolla, teoksen vuonna 1971 julkaistun kolmannen suomennoksen synty liittyy sekin yhteen suomalaisen kustannustoiminnan murrosvaiheeseen. Kolmannen suomennoksen kustantaja, Ex Libris -kirjakerho, aloitti toimintansa vuonna 1968 ja oli ensimmäinen kansainvälisen mallin mukainen, postimyyntiin perustuva kirjakerho Suomessa (Paketteja 2012). Ex Libris julkaisi kaunokirjallisuussuomennoksia vuoteen 1975 asti, ja sen valikoimaan kuului paljon klassikkoja, muun muassa David Copper- 
field ja kaksi muuta Dickensin romaania. Suuri osa julkaisuista oli uusia painoksia jo olemassa olevista suomennoksista - joukossa myös useampi Hollon tekemä suomennos - mutta David Copperfieldista teetettiin poikkeuksellisesti uusi käännös. Hollon suomennoksen ilmestymisestä oli toki ehtinyt kulua jo 47 vuotta, mutta suomennospäätökseen ovat saattaneet vaikuttaa myös käännöksen julkaisuoikeuksiin liittyvät syyt.

Joka tapauksessa Hollon suomennos ilmeisesti koettiin tässä vaiheessa vanhentuneeksi, sillä Karisto teetti siitä korjatun version vuonna 1974 julkaistua kolmatta painosta varten. Suurin osa korjauksista on kielenhuoltoon liittyviä: sanavalintoja, sanajärjestyksen korjaamista inversiosta suoraksi ja oikeinkirjoituksen ajanmukaistamista. Osa korjauksista kuitenkin liittyy myös teoksessa esiintyviin kulttuurisidonnaisiin käsitteisiin ja ilmauksiin; käsittelen näitä tarkemmin jäljempänä.

David Copperfieldin kolmannesta suomentajasta, Heidi Järvenpäästä (synt. 1924), löytyy niukasti tietoa, mutta Fennica-tietokannan perusteella hän oli tuottelias suomentaja, joka aloitti uransa 1950-luvulla ja suomensi muun muassa Doris Lessingin teoksia sekä Enid Blytonin Viisikko-sarjaa. Järvenpään suomennoksen esipuheeksi on kopioitu Rafael Koskimiehen Maailman kirjallisuus -sarjaan (1965, 69-73) kirjoittama Dickens-esittely, jossa Dickens kuvataan suureksi kertojaksi, kaikkine puutteineenkin, sekä korostetaan hänen saavuttamaansa suosiota "koko Euroopan kansankertojana", siis populaarina klassikkona.

Järvenpään David Copperfield -suomennos on käännöksistä uusin, mutta myöhemmän julkaisuhistorian perusteella se ei ole jäänyt elämään: siitä ei ole otettu uusintapainoksia, ja sen levinneisyys näyttää rajoittuneen Ex Libris -kirjakerhon tilaajiin. Hollon suomennoksesta taas on otettu uusintapainos (7. painos) viimeksi vuonna 1991. Tämä lopputulos ei kuitenkaan välttämättä kerro mitään suomennosten keskinäisestä paremmuudesta; on mahdollista, että Järvenpään suomennoksellakin olisi ollut toisenlainen kohtalo jonkin vakiintuneemman kustantajan julkaisemana.

\section{Käännösstrategioiden käyttö David Copperfieldin suomennoksissa}

Dickensin teos sijoittuu 1800-luvun puolivälin Englantiin ja kuvaa oman aikansa englantilaista yhteiskuntaa. Suomentajien on siis pitänyt ratkaista, miten välittää suomennoksessa lähtötekstin kulttuurisidonnaiset ilmiöt ja viittaukset, jotka olivat todennäköisesti suurelta osin vieraita varsinkin 1800-luvun lopun ja 1900-luvun alun suomalaisille lukijoille.

Kulttuurisidonnaiset käsitteet, ilmaukset ja alluusiot ovat käännöstutkimuksessa mielenkiintoisia, koska niitä ei pysty kääntämään suoraan. Kääntäjälle ne muodostavat paikallisen käännösongelman, jonka ratkaisemiseen hän voi käyttää erilaisia strategioita. Tällaisia ovat esimerkiksi vieraan käsitteen korvaaminen käännöksen lukijoille tutummalla käsitteellä tai vähemmän kulttuurisidonnaisella yläkäsitteellä, tekstinsisäinen selvennys, tekstinulkoinen selvennys ala- tai loppuviitteessä tai poisto (Leppihalme 
2001, 141). Yksittäisten, paikallisten käännösongelmien ratkaisemisessa käytetyt strategiat heijastavat laajempaa, koko tekstiä koskevaa globaalia strategiaa, jonka kääntäjä on valinnut. Käännöstutkimuksessa puhutaan usein kotouttavista ja vieraannuttavista käännöksistä: kotouttava käännöstapa pyrkii tuomaan teoksen lukijan lähelle mukauttamalla sen kohdekulttuurin kirjallisiin konventioihin ja poistamalla tai korvaamalla tekstissä esiintyvät vieraat kulttuurisidonnaiset elementit. Vieraannuttava käännöstapa taas pyrkii säilyttämään alkuteoksessa esiintyvät vieraat elementit myös käännöksessä ja korkeintaan lisäämään niihin selityksiä; uskollisuus alkutekstille on tärkeämpää kuin mahdollisimman sujuva lukukokemus.

Valittujen globaalien ja paikallisten strategioiden taustalla vaikuttaa monia tekijöitä, kuten ajan yleiset käännösnormit ja -käytännöt, kääntäjän ja kustantajan käsitykset käännettävästä teoksesta, kohdeyleisöstä sekä siitä, miten tiettyjä lajityyppejä tai tietylle kohdeyleisölle suunnattuja tekstejä tulisi kääntää, kääntäjän suhde lähtö- ja kohdekulttuuriin, sekä tietysti myös kääntäjän oma kielellinen ja kääntämiseen liittyvä kompetenssi. Käännösratkaisujen pohjalta voidaan näin tarkastella laajemminkin kääntäjän käännösprosessissa käyttämiä strategioita ja periaatteita. Tällä tavalla ne tekevät kääntäjän ja käännösprosessin ikään kuin näkyväksi itse käännöksessä.

Churbergin käyttämistä käännösstrategioista huomiota herättää erityisesti alaviitteiden käyttö: suomennoksessa on yhteensä 41 alaviitettä, joissa Churberg selittää tekstissä esiintyviä sanoja, ilmauksia ja viittauksia, joiden olettaa olevan suomalaisille lukijoille vieraita. Alaviitteiden käyttö oli yleistä 1800-luvun ja 1900-luvun alun suomennoksissa, varsinkin arvokkaammassa kirjallisuudessa (Paloposki 2010, 86-107). Aikalaisarvostelujen perusteella voi päätellä, että kyseessä oli hyväksytty ja jopa suositeltu käännösstrategia. ${ }^{5}$ Suomen lisäksi alaviitteiden käyttö näyttää olleen 1800-luvulla yleistä ainakin ruotsalaisessa ja saksalaisessa käännöskirjallisuudessa. ${ }^{6}$ Churbergin käännösten ilmestymisaikaan porvarillinen lukijakunta tutustui ulkomaiseen kaunokirjallisuuteen vielä suurimmaksi osaksi ruotsinkielisten käännösten kautta, joten on luonnollista, että suomentajien käyttämät käännösstrategiat ja -normit vastasivat ruotsalaisista käännöksistä saatua mallia. Esimerkiksi vuonna 1872 julkaistuissa kahdessa David Copperfieldin ruotsinnoksessa (kääntäjinä Gustaf Thomée ja C. J. Backman) on kääntäjän alaviitteitä lähes samassa suhteessa kuin Churbergin suomennoksessa.

Churbergille juuri alaviitteiden käyttö näyttää olleen ensisijainen strategia selvittää kulttuurisidonnaisia käännösongelmia. Viitteissä hän selittää pääasiassa erisnimiä, englantilaisia titteleitä ja puhuttelutapoja, mittayksiköitä ja rahoja, yhteiskuntaan ja kulttuuriin liittyviä ilmiöitä kuten pelejä tai juomia, sanaleikkejä sekä historiaan tai kirjallisuuteen liittyviä viittauksia. Churbergin antamat selitykset ovat pääasiassa lyhyitä, esimerkiksi "Gin = katajaviina" (Dickens 1879-1880, I 274). Englantilaisen kulttuurin vierautta 1800-luvun Suomessa kuvastaa se, että Churbergin alaviitteet lähtevät liikkeelle perusasioista: suomennoksessa on säilytetty lähes kaikki englantilaiset tittelit 
nimien edellä alkuperäisessä muodossaan ( $\mathrm{Mr}, \mathrm{Mrs}$, Master jne.), ja suurin osa näistä on selitetty lyhyesti alaviitteessä ensiesiintymisen yhteydessä (esim. "Mr. = Mister (herra)" (Dickens 1879-1880, I 6). Tässä on myös selkein ero suomennoksen ja ruotsinnosten alaviitteiden välillä: ruotsinnoksissa käytetään samalla tavoin englantilaisia titteleitä, mutta ilmeisesti ne olivat ajan ruotsalaislukijoille jo tuttuja monista edeltävistä käännöksistä eivätkä vaatineet enää selityksiä. ${ }^{7}$

Vaikka Churberg käyttää runsaasti alaviitteitä, yleisvaikutelma on, että paljon kulttuurisidonnaisia, lähtökieleen ja -kulttuuriin liittyviä käsitteitä jätetään selittämättä. Useimpien kulttuurisidonnaisten käännösongelmien käsittelyssä uskollisuus lähtötekstille näyttää olleen ensisijainen periaate ja tekstin sovittaminen kohdeyleisölle toissijaista. Churbergin käännöstapaa voikin kutsua vieraannuttavaksi: alaviitteisiin lisätyt selitteet auttavat lukijaa ymmärtämään vieraita elementtejä, mutta samalla ne myös korostavat tekstin sijoittumista lukijalle vieraaseen maailmaan (Leppihalme 2007, 372).

Kun verrataan Churbergin suomennosta Holloon, on mielenkiintoista havaita selvä muutos käännösstrategioissa. Monet kulttuurisidonnaiset ilmaisut ja viittaukset, jotka Churberg selittää alaviitteissä, on Hollon suomennoksessa joko selvennetty itse tekstissä, korvattu yläkäsitteellä tai suomalaisille tutummalla vastineella tai jätetty kokonaan pois. Esimerkiksi 'cricket' on Hollon suomennoksessa 'pallopeli' ja 'gin' 'paloviina'. Muutos ei siis tässä vaiheessa ole tapahtunut siinä, mitä kääntäjä on olettanut lukijan tietävän, vaan siinä, miten toinen kääntäjä on ratkaissut saman ongelman. Hollon globaali käännösstrategia on selvästi kotouttavampi kuin Churbergin: teksti tuodaan lähemmäksi lukijaa häivyttämällä siitä sellaisia lähtökulttuuriin liittyviä tekijöitä, jotka eivät välttämättä avaudu lukijalle.

Joissain tapauksissa Hollo on päätynyt samaan käännösratkaisuun kuin Churberg, mutta ilman selittäviä alaviitteitä. Esimerkiksi titteleiden kohdalla Hollo on säilyttänyt alkuperäiset puhuttelumuodot, mutta toisin kuin Churberg, hän saattoi luottaa siihen, että suomennoskirjallisuuden lisääntymisen myötä nämä olivat jo käyneet lukijakunnalle riittävän tutuiksi. Sekä Churberg että Hollo ovat myös kääntäneet englantilaisen mittayksikön 'mile' peninkulmaksi, mutta vain Churberg on katsonut tarpeelliseksi huomauttaa alaviitteessä, että kyse on englantilaisista peninkulmista "joita menee lähes 7 Suomen peninkulmaan" (Dickens 1879-1880, I 85). Siinä missä Churberg kiinnittää alaviitteissään huomiota yksityiskohtiin ja siihen, että lukija ymmärtää ne oikein, Hollo vaikuttaa painottaneen tarkkuuden sijaan käännöksen yleistä sujuvuutta.

Järvenpään suomennos ja Hollon suomennoksen tarkistettu painos tarjoavat ajallisen läheisyytensä ja poikkeavien ratkaisujensa vuoksi toisen hedelmällisen tarkasteluparin. Järvenpään suomennos vaikuttaa ainakin kulttuurisidonnaisten elementtien osalta pysyttelevän hieman lähempänä alkutekstiä kuin Hollon 47 vuotta varhaisempi suomennos. Tähän on varmasti vaikuttanut se, että englantilainen kulttuuri ja yhteiskunta olivat 1970-luvulla jo huomattavasti tutumpia suomalaisille lukijoille: esimerkiksi 
'cricket' on Järvenpään suomennoksessa 'kriketti' ja 'gin' on 'gini', ja matkat ilmaistaan alkuteoksen mukaisesti maileina. Jotkin teoksen elementit ovat toisaalta muuttuneet vieraammiksi ajallisen etäisyyden myötä, minkä seurauksena suomennoksesta löytyy ajallisesti kotouttavia käännösratkaisuja: alkuteoksen kulkuneuvo, jota kuvaillaan sanoin "half chaise-cart, half pianoforte van" (Dickens 1992, 122), on Hollon suomennoksessa vielä "jonkinlainen rillain ja huonekaluvaunujen välimuoto" (Dickens 1924, I 181), Järvenpään suomennoksessa taas todetaan yksinkertaisesti "vaunut olivat pitkät ja nelipyöräiset" (Dickens 1971, I 149). ${ }^{8}$

Hollon suomennoksen tarkistetussa laitoksessa sen sijaan siirrytään kauemmas alkuteoksesta, sillä siihen on kielellisten korjausten lisäksi tehty entistä enemmän kotouttavia muutoksia. Välimatkat on muunnettu Hollon käyttämistä peninkulmista kilometreiksi, ja esimerkiksi "oikea ruutisalaliitto" on muutettu muotoon "todellinen salaliitto", jolloin Hollon suomennoksessaan säilyttämä kulttuurisidonnainen viittaus katoaa (Dickens 1924, I 211; 1974, I 183). Selvin muutos on titteleiden suomentamisessa: Hollo käytti suomennoksessaan alkuperäisiä englantilaisia titteleitä, mutta korjatussa laitoksessa, samoin kuin Järvenpään käännöksessä, ne on muutettu suomenkielisiksi (herra, rouva, nuoriherra jne.). Vielä 1900-luvun alkupuolen Dickenssuomennoksissa titteleihin ja puhutteluihin liittyvät ratkaisut vaihtelivat teoksesta ja suomentajasta toiseen, mutta mahdollisesti 1970-luvulle tultaessa oli jo olemassa selkeä käytäntö tai normi niiden suomentamisesta. Titteleiden järjestelmällinen muuttaminen korjatussa painoksessa kertoo, että ainakin kustannustoimittaja on katsonut asian vaativan korjaamista.

Yleinen käännösstrategioiden muutos 1800-luvulta 1900-luvun jälkipuoliskolle näkyy selkeimmin alaviitteiden käytössä. Hollon suomennoksessa on vain yksi alaviite, ja siinä selitetään viittaus, jota ei ole selitetty Churbergin käännöksessä. Alaviitteen olemassaolo kuitenkin kertoo siitä, että myös Hollolle käsitteen tai viittauksen selittäminen alaviitteessä oli yksi mahdollinen käännösstrategia, alaviitteet ikään kuin kuuluivat hänen suomentajan "työkalupakkiinsa". ${ }^{9}$ Sen sijaan 1900-luvun jälkipuoliskolla alaviitteet näyttävät poistuneen lähes kokonaan käytöstä. Hollon suomennoksen yksinäinen alaviite onkin siivottu pois vuoden 1974 korjatusta painoksesta, eikä Järvenpään suomennoksessa ole myöskään käytetty alaviitteitä - tässä vaiheessa niiden käyttö käännösstrategiana ei välttämättä ollut enää edes todellinen vaihtoehto suomentajalle.

\section{Käännösstrategioiden suhde teoksen asemaan ja kohdeyleisöön}

Mitä suomennoksissa käytetyt käännösstrategiat ja kulttuurisidonnaisten käännösongelmien kohdalla tehdyt ratkaisut sitten kertovat laajemmin näistä suomennoksista ja siitä, miten Dickensin teosta ja sen kontekstia pyrittiin välittämään suomalaisille lukijoille? Entä keitä olivat ne suomalaiset lukijat, joille suomennokset oli osoitettu? Kuten johdannossa totesin, kääntäjältä edellytetään kahdensuuntaista uskollisuutta: 
toisaalta uskollisuutta alkutekstille, toisaalta taas käännöksen lukijoiden palvelemista. David Copperfieldin suomentajat ovat ottaneet molemmat vaatimukset huomioon, mutta keskenään eri tavoin.

Churbergin David Copperfield -suomennoksessa alkuperäisen teoksen kunnioitus vaikuttaa välillä olleen tärkeämpää kuin vieraiden kulttuurisidonnaisten elementtien selventäminen suomalaislukijoille. Suomennoksessa on alaviitteiden selityksistä huolimatta runsaasti sellaisia vierassanoja ja alluusioita, jotka on jätetty lukijan tietämyksen varaan. Tämä vastaa André Lefeveren $(1992,31)$ väittämää, jonka mukaan käännös pysyttelee todennäköisesti mahdollisimman lähellä lähtötekstiä, jos alkuteoksella on hyvin positiivinen maine kohdekulttuurissa. Churbergin suomennostapa korosti siis teoksen asemaa arvokkaana kirjallisuuden klassikkona. On jopa perusteltua kysyä, kumpi oli Churbergin ensisijainen tavoite: saattaa Dickensin teos suomalaisille lukijoille, vai saattaa se suomen kielelle ja yhdistää se näin osaksi suomenkielistä kirjallisuutta, koska kyseessä oli ajan määritelmän mukaan klassillinen teos, joka kuului osaksi kaikkien sivistyneiden kansojen kirjallisuusvarantoa, kuten Churberg toteaa ilmoituksessaan kirjasarjansa tavoitteista.

Toinen Churbergin suomennostapaan vaikuttanut tekijä oli hänen kohdeyleisönsä: teosvalinnan, romaanisarjan ilmoitettujen tavoitteiden ja jopa käytetyn kirjasinlajin, antiikvan, perusteella suomennosta ei ollut suunnattu niinkään tavalliselle kansalle vaan ensisijaisesti sivistyneistölle. ${ }^{10}$ Tämä yleisö oli todennäköisesti jo tutustunut Dickensiin ruotsinkielisten käännösten kautta. Niinpä lukijoiden saattoi olettaa tuntevan ennestään Dickensin teosten maailmaa, jota oli selitetty ruotsinnosten alaviitteissä. Tämä voi olla yksi selitys sille, miksi Churbergin suomennos on vähemmän kotouttava kuin Hollon myöhempi uudelleenkäännös. Churberg pyrki silti ottamaan huomioon myös uudet lukijat selittämällä esimerkiksi tittelit, jotka ovat teoksessa yleisimmin toistuvia kulttuurisidonnaisia elementtejä.

Hollon kotouttavamman globaalin strategian taustalla taas vaikutti mahdollisesti Dickensin arvostuksen heikkeneminen, yleisemmät muutokset käännösstrategioissa ja hyvää käännöstä koskevissa käsityksissä (esimerkiksi alaviitteiden käytön vähentyminen), sekä kääntäminen selkeästi suomenkieliselle yleisölle, jolle englannin kieli ja kulttuuri oli yhä jokseenkin vieras. Tärkeä tekijä oli myös Hollon oma suomennostyyli, joka pysyi varsin samanlaisena teoksesta ja kirjailijasta toiseen (Kovala 2007, 591). Lisäksi kustantajan toiveet ja odotukset ovat saattaneet vaikuttaa käännösratkaisuihin: siinä missä Churberg kustansi omat käännöksensä, Hollon toimeksiantajana oli vakiintunut kaupallinen kustantamo Karisto. Vaikka suomennos julkaistiin klassikkosarjassa, teoksen epäilemättä toivottiin saavuttavan laajan lukijakunnan eikä pelkästään sivistynyttä eliittiä.

On huomattava, että Hollon suomennoksen kotouttavuus koskee ainakin kulttuurisidonnaisten elementtien osalta lähinnä yksittäisiä käsitteitä tai viittauksia, joilla 
ei ole laajempaa merkitystä kertomuksen kannalta. Esimerkiksi Dickensin kuvaama englantilainen oikeuslaitosjärjestelmä esitetään kaikissa suomennoksissa yhtä kryptisenä ja monipolvisena kuin alkuteoksessa (tähän kuvaukseen ei Churbergkaan ole liittänyt alaviitteitä). Kulttuurisidonnaisten elementtien korvaaminen esimerkiksi kulttuurineutraaleilla yläkäsitteillä lähinnä vähentää teoksen englantilaista paikallisväriä. Vastaavasti Järvenpään suomennoksessa on häivytetty joitain 1800-luvun materiaaliseen kulttuuriin liittyviä käsitteitä, tällä kertaa ajallisen eikä kulttuurisen etäisyyden vuoksi. Erot kulttuurisidonnaisten elementtien käsittelyssä Hollon ja Järvenpään suomennosten välillä näyttävätkin vastaavan suomalaisen lukijakunnan kulttuurisessa tietämyksessä tapahtunutta muutosta, eli toisaalta englannin kieleen ja kulttuuriin liittyvän tietämyksen kasvua, toisaalta taas etääntymistä 1800-luvun materiaalisesta kulttuurista.

Juuri tästä syystä Hollon suomennoksen tarkistettu laitos toimii mielenkiintoisena kontrastina Järvenpään suomennokselle. Samoin kuin Churbergin tarkasti alkutekstiä noudattava suomennos, se osoittaa, että kotouttamista tai vieraannuttamista koskevat ratkaisut eivät riipu pelkästään yleisestä lähdekulttuuria koskevasta tietämyksestä kohdekulttuurissa, vaan myös siitä, kenelle ja mihin tarkoitukseen käännös on suunnattu. Vaikuttaa siltä, että Hollon suomennokseen tehtyjen kotouttavien korjausten tavoitteena oli muokata teoksesta entistä selkeämmin helposti sulava lukuromaani. Sarjat, joissa Hollon suomennos 1900-luvun jälkipuoliskolla julkaistiin, kertovat osaltaan muutoksesta teoksen asemassa ja siihen liitetyissä mielikuvissa: kolmas, korjattu painos ilmestyi "Kotien suurromaanit" -sarjassa, ja myöhemmin se on julkaistu sarjoissa "Suuri lukukirjasto" ja "Suuri kotikirjasto". Teos on siis myös sarjakontekstinsa perusteella pyritty esittämään ensisijaisesti joka kodin lukuromaanina eikä klassikkona, kuten 1800-luvulla ja 1900-luvun alkupuolella. Tarkistettu laitos on lisäksi hyvä esimerkki siitä, miten kustantajat ja kustannustoimittajat voivat osaltaan vaikuttaa käännökseen.

Titteleiden suomentaminen 1970-luvulla julkaistuissa David Copperfieldin suomennoksissa tuo esiin toisen mielenkiintoisen ristiriidan. Voisi olettaa, että sitä mukaa kun vieraaseen kieleen ja kulttuuriin liittyvät ilmiöt tulevat tutummiksi, myös tarve kotouttaa tällaisia kulttuurisidonnaisia elementtejä vähenee. Mahdollisesti asia onkin niin, että vieraannuttavia piirteitä siedetään vähemmän lähikulttuureista peräisin olevissa käännöksissä. 1800-luvun ja 1900-luvun alun käännösten alaviitteet ja alkutekstin puhuttelumuodot korostivat tekstin sijoittumista lukijan kannalta vieraaseen maailmaan, kun taas kulttuurisidonnaisten piirteiden häivyttäminen palvelee läheisiin kulttuureihin liitettyä tuttuuden ja samuuden illuusiota.

\section{Lopuksi}

Suomentajan käännösstrategiat vaikuttavat olennaisesti siihen, millaisen kuvan suomalaiset lukijat saavat teoksesta. Sekä paikalliset että globaalit käännösstrategiat ovat ratkaisuja, joita kääntäjät ja kustantajat tekevät teoksen kokonaisuuden ja aiotun kohde- 
yleisön perusteella: mikä on olennaista teokselle, mikä taas lukijoille, ja miten nämä kaksi saadaan parhaiten kohtaamaan. Pelkästään kulttuurisidonnaisia elementtejä koskevien käännösratkaisujen perusteella ei pysty tekemään johtopäätöksiä siitä, miten hyvin kukin suomentaja on onnistunut välittämään esimerkiksi Dickensin kerrontatavan tai huumorin, tai miten toimiva suomennos ylipäänsä on. Sen sijaan käännösratkaisut tarjoavat ikkunan siihen, miten kukin kääntäjä on hahmottanut yleisönsä sekä tehtävänsä välittäjänä alkutekstin ja lähtökulttuurin sekä kohdekielen ja -kulttuurin välillä.

David Copperfieldin suomennokset ja niissä käytetyt käännösstrategiat kuvastavat oman aikansa käytäntöjä ja käsityksiä hyvästä käännöksestä sekä sitä, millaisena Dickens on kulloinkin tahdottu välittää suomalaisille lukijoille: onko kyseessä ulkomainen mestariteos, jonka suomennos jo olemassaolollaan rikastuttaa suomenkielistä kirjallisuutta, vai viihdyttävä lukuromaani mahdollisimman laajalle yleisölle. Teosta koskevat mielikuvat ja käännöksessä käytetyt strategiat ovat vuorovaikutuksessa keskenään ja myös vahvistavat toisiaan - on mahdollista, että sama teos on yhdellä kielellä monitulkintainen klassikko ja toisella kielellä viihdyttävää ajanvietettä. David Copperfieldin tapauksessa suomentajien ja kustantajien ratkaisut ovat sekä heijastaneet että tukeneet teoksen muuntumista klassikosta lukuromaaniksi suomalaisessa kirjallisuuskontekstissa.

\section{Viitteet}

${ }^{1}$ Käännöstutkimuksessa usein lainattu Gideon Touryn $(1995,29)$ toteamus: “[T]ranslations are facts of target cultures".

${ }^{2}$ Waldemar Churbergin toiminnasta suomentajana ja kustantajana, ks. Vuokko (2013);

Churbergin myöhemmistä värikkäistä vaiheista, ks. Keskisarja (2010).

${ }^{3}$ David Copperfieldin lisäksi englantilaista kaunokirjallisuutta edustivat listalla William Shakespeare, Walter Scott, Jonathan Swiftin Gulliverin retket, ja Laurence Sternen Tristram Shandy. ${ }^{4}$ Tämä käy ilmi esimerkiksi O. A. Joutsenen Pickwick-klubin muistelmat-suomennoksen (1907) esipuheesta, jossa hän luettelee Dickensin siihen mennessä suomennetut romaanit ja toteaa David Copperfieldin kohdalla: "valitettavasti jo vanhentuneessa asussa".

${ }^{5}$ Esimerkiksi Antti Jalavan suomennosta Jókain romaanista Uusi tilanhaltia koskevassa Uuden Suomettaren arvostelussa alaviitteiden käyttö mainitaan hyväksyvästi: "Tekstin alle on suomentaja pannut koko joukon tarpeellisia ja valaisevia selityksiä yksityisistä sanoista, valtiollisista seikoista y. m.” (9.12.1878). Kirjallisen Kuukauslehden samaa teosta koskevassa arvostelussa sen sijaan kritisoidaan suomennosta liiallisesta vierassanojen käytöstä ja luetellaan latinankielisiä termejä, "joita ainakin olisi pitänyt tekstin alla selittää" (KKl 4/1879). Jalavan suomennoksessa on yhteensä 70 alaviitettä.

${ }^{6}$ Olen ottanut vertailuaineistoksi Turun yliopiston kirjaston kokoelmista viisikymmentä 1800-luvulla ilmestynyttä ruotsinnettua ja saksannettua romaania ja novellikokoelmaa, ja näistä noin 80 prosenttia sisälsi alaviitteitä.

${ }^{7}$ Churbergin alaviitteet eroavat ytimekkyydessän teoksen 1800-luvun ruotsinnosten alaviitteistä: erityisesti Backman pyrkii viitteissään tarjoamaan lukijoille enemmän taustatietoa englantilaisesta yhteiskunnasta ja tavoista. Churberg selittää laveammin lähinnä historiallista viittausta Guy Fawkesiin ja ruutisalaliittoon.

${ }^{8}$ Churberg (Dickens 1879-1890, I 147) on kääntänyt kohdan hyvin kirjaimellisesti "puoli- 
kääsykärryiksi ja puoli-pianovankkureiksi”.

${ }^{9}$ Hollo ei vaikuta olleen erityisen innokas alaviitteiden käyttäjä: esimerkiksi Hollon suomennoksessa Goethen Vaaliheimolaiset -romaanista (1923) on siinäkin vain yksi alaviite.

Toisaalta ainakin Gulliverin retkien ja Don Quijoten suomennoksiin Hollo on lisännyt runsaasti selityksiä ja taustatietoa loppuviitteisiin.

${ }^{10}$ Fraktuura säilyi hallitsevana kirjasinlajina kansalle tarkoitetussa kirjallisuudessa vielä 1900luvun alkupuolelle asti, kun taas koulutetulle väestölle tarkoitettu kirjallisuus painettiin jo 1800-luvulla yleisimmin antiikvalla (Havu 1988, 129).

\section{Lähteet}

\section{Primäärilähteet}

Dickens, Charles 1992 (1850). David Copperfield. Ware: Wordsworth.

Dickens, Charles 1872. David Copperfield den yngre frain Blunderstone Rookery, hans lefnad, äfventyr, hågkomster och iakttagelser I-II. 2. genomsedda uppl. Övers. Gustaf Thomée. Stockholm: Bonniers.

Dickens, Charles 1872. David Copperfield den yngres lefnadshistoria och erfarenhet af lifvet I-II. Övers. C. J. Backman. Stockholm: F. \& G. Beijers.

Dickens, Charles 1879-1880. David Copperfield nuoremman elämänkertomus ja kokemukset I-II. Suom. W. Churberg. Helsinki: Churberg.

Dickens, Charles 1907. Pickwick-klubin muistelmat. Suom. O. A. Joutsen. Porvoo: O. Räisänen ja Kumpp.

Dickens, Charles 1924. David Copperfield I-II. Suom. J. Hollo. Hämeenlinna: Karisto.

Dickens, Charles 1971. David Copperfield I-III. Suom. Heidi Järvenpää. Helsinki: Ex Libris.

Dickens, Charles 1974 (1924). David Copperfield I-II. Suom. J. Hollo. Neljäs [korjattu] painos. Hämeenlinna: Karisto.

\section{Aikalaisarvostelut}

Kirjallinen Kuukauslehti (KKl) 4/1879, 11/1880.

Morgonbladet 19.12.1879.

Uusi Suometar 13.3.1872, 9.12.1878, 15.12.1879.

Valvoja 13-14/1883.

\section{Sekundäärilähteet}

Eneberg, Märta 1960. Charles Dickens i sin samtids Finland. Torsten Steinby (red.), Historiska och litteraturhistoriska studier 35. Helsingfors: SLS, 332-356.

Havu, Sirkka 1988. Suomalaisen kirjan tyylihistoriaa. Esko Häkli (toim.), Kirja Suomessa. Helsinki: Helsingin yliopiston kirjasto, 119-136.

Hollington, Michael 2013. Introduction. Michael Hollington (ed.), The Reception of Charles Dickens in Europe I. London: Bloomsbury. 1-15. 
Hollo, J. 1924. Charles Dickens. Esipuhe Dickensin romaaniin David Copperfield I-II (1924), 5-10.

Häggman, Kai 2008. Paras tawara maailmassa. Suomalainen kustannustoiminta 1800luvulta 2000-luvulle. Helsinki: Otava.

Keskisarja, Teemu 2010. Vä̈peli T:n tapaus ja muita kertomuksia suomalaisesta terrorista. Jyväskylä: Atena.

Koskimies, Rafael 1965. Dickens. Maailman kirjallisuus IV. Helsinki: Otava, 69-53. Uudelleenjulkaistu Dickensin romaanissa David Copperfield I-III (1971), 5-8.

Kovala, Urpo 1992. Väliin lankeaa varjo. Angloamerikkalaisen kaunokirjallisuuden välittyminen Suomeen 1890-1939. Nykykulttuurin tutkimusyksikön julkaisuja 29. Jyväskylä: Jyväskylän yliopisto.

Kovala, Urpo 2007. J. A. Hollo (1885-1967). H. K. Riikonen et al. (toim.), Suomennoskirjallisuuden historia 1. Helsinki: SKS, 587-591.

Lefevere, André 1992. Translation, Rewriting, and the Manipulation of Literary Fame. London: Routledge.

Leppihalme, Ritva 2001. Translation Strategies for Realia. Pirjo Kukkonen \& Ritva Hartama-Heinonen (eds.), Mission, Vision, Strategies, and Values. A Celebration of Translator Training and Translation Studies in Kouvola. Helsinki: Helsinki University Press, 139-147.

Leppihalme, Ritva 2007. Kääntäjän strategiat. H. K. Riikonen et al. (toim.), Suomennoskirjallisuuden historia 2. Helsinki: SKS, 365-373.

Paketteja, postimyyntiä ja verkkokauppaa - Hobby Hall 50 vuotta suomalaisten arjessa. Lehdistötiedote 19.6.2012. http://www.stockmanngroup.fi/hobby-hall-50-vuotta (19.9.2014).

Paloposki, Outi 2010. The Translator's Footprints. Tuija Kinnunen \& Kaisa Koskinen (eds.), Translators' Agency. Tampere Studies in Language, Translation and Culture, Series B4. Tampere: Tampere University Press, 86-107. urn.fi/ urn:isbn:978-951-44-8082-9 (19.9.2014).

Paloposki, Outi \& Kaisa Koskinen 2010. Reprocessing Texts. The Fine Line between Retranslating and Revising. Across Languages and Cultures 11(1), 29-49.

Rantavaara, Irma 1965. Suurennuslasi. Tutkielmia ja esseitä kirjallisuudesta. Helsinki: Otava.

Riikonen, H. K. 2013. Dickens's Reception in Finland. Hollington, Michael (ed.), The Reception of Charles Dickens in Europe II. London: Bloomsbury, 388-398.

Toury, Gideon 1995. Descriptive Translation Studies and Beyond. Amsterdam: Benjamins.

Vuokko, Katja 2013. "Suoranainen ja välitön työ ja toimi suomalaisuuden ja suomen kielen hyväksi". Waldemar Churberg (1848-1924) suomentajana ja kustantajana sekä hänen David Copperfield -suomennoksensa. Pro gradu -tutkielma. Turun yliopisto. 